\title{
HASIL BELAJAR KETERAMPILAN LARI CEPAT
}

\author{
Samsul Bahri', Yusuf Adisasmita ${ }^{2}$, dan Moch. Asmawi ${ }^{2}$ \\ ${ }^{1}$ Sekolah Farmasi Institut Teknologi Bandung \\ ${ }^{2}$ Fakultas Ilmu Keolahragaan Universitas Negeri Jakarta \\ email: samsul@fa.itb.ac.id
}

\begin{abstract}
Abstrak: Tujuan penelitian adalah menemukan efektivitas model pendekatan pembelajaran Kid's Athletics dan model konvensional terhadap hasil belajar keterampilan lari cepat. Metode penelitian yang digunakan adalah eksperimen dengan disain penelitian treatment by level $2 \times 2$. Penelitian dilaksanakan di Sekolah Dasar Prof. Dr. Moestopo Kota Bandung. Data diperoleh lewat tes lari, sedang analisis data dilakukan dengan teknik statistik analisis varian. Hasil penelitian menyimpulkan hal-hal berikut. (1) Secara keseluruhan, model pembelajaran Kid's Athletics lebih tinggi pengaruhnya daripada model pembelajaran Konvensional terhadap hasil belajar keterampilan lari cepat. (2) Terdapat interaksi antara model pembelajaran dan koordinasi mata tangan kaki terhadap hasil belajar keterampilan lari cepat. (3) Siswa yang memiliki koordinasi mata tangan kaki tinggi, model pembelajaran Kid's Athletics lebih tinggi pengaruhnya dari model pembelajaran konvensional terhadap hasil belajar keterampilan lari cepat. (4) Siswa yang memiliki koordinasi mata tangan kaki rendah, model pembelajaran Kid's Athletics lebih rendah pengaruhnya dari model pembelajaran konvensional terhadap hasil belajar keterampilan lari cepat.
\end{abstract}

Kata Kunci: konvensional, kid's athletics, koordinasi, lari cepat

\section{THE OUTCOMES OF SPRINT SKILLSLEARNING (An Experimental Study at Prof. Dr. Moestopo Primary School in Bandung, West Java)}

\begin{abstract}
The purpose of this study is to reveal the effectiveness of the use of Kid's Athletics and conventional learning approaches in relation to the outcomes of sprint skills learning. The method used was an experimental research design treatment by level $2 \times 2$. The experiment was conducted at elementary schools of Prof. Dr Moestopo in Bandung, West Java, in 2013. It was found that: (1) overall, the Kid's Athletics approach had higher effect on the outcomes of sprint skills learning than that of the conventional learning model, (2) there was an interaction between the learning model and hand-eye-foot coordination in the outcomes of sprint skills learning, (3) regarding the students who have high hand-eye-foot coordination, the Kid's Athletics had higher effect on the outcomes of sprint skills learning than the conventional one, and (4) regarding the students who have low hand-eye-foot coordination, the Kid's Athletics model had less effect on the outcomes of sprint skills learning than the conventional one.
\end{abstract}

\section{Keywords: conventional, kid's athletics, coordination, sprint}

\section{PENDAHULUAN}

Pendidikan jasmani merupakan bagian integral dari sistem pendidikan secara keseluruhan. Untuk hal itu, maka dalam pelaksanaan pendidikan jasmani harus diarahkan pada pencapaian tujuan pendidikan. Tujuan pendidikan jasmani bukan aktivitas jasmani itu sendiri, tetapi untuk mengembangkan potensi (multiple intellegences) siswa melalui aktivitas jasmani. Media yang digunakan dalam aktivitas jasmani bisa melalui permainan, olahraga, dan lingkungan.

Persepsi yang sempit dan keliru terhadap pendidikan jasmani akan mengakibatkan nilai- nilai luhur dan tujuan pendidikan yang terkandung di dalamnya tidak akan tercapai. Orientasi pembelajaran pendidikan jasmani harus disesuaikan dengan perkembangan siswa, materi, dan cara penyampaiannya harus disesuaikan, sehingga pembelajaran menjadi menarik dan menyenangkan. Sasaran pembelajaran bukan hanya ditujukan untuk mengembangkan keterampilan olahraga, tetapi perkembangan pribadi siswa seutuhnya. Konsep dasar pendidikan jasmani dan model pengajaran pendidikan jasmani yang efektif perlu dipahami oleh setiap guru pendidikan jasmani. 
Pengertian pendidikan jasmani sering dikaburkan dengan konsep lain, dimana pendidikan jasmani disamakan dengan setiap usaha atau kegiatan yang mengarah pada pengembangan organorgan tubuh manusia (body building), kesegaran jasmani (physical fitness), kegiatan fisik (physical activities), dan pengembangan keterampilan (skill development). Pengertian tersebut memberikan pandangan yang sempit dan menyesatkan terhadap arti pendidikan jasmani yang sebenarnya. Walaupun memang benar aktivitas fisik itu mempunyai tujuan tertentu, namun karena tidak dikaitkan dengan tujuan pendidikan, maka kegiatan itu tidak mengandung unsur-unsur pedagogi.

Pendidikan jasmani bukan hanya merupakan aktivitas pengembangan fisik secara terisolasi, akan tetapi harus berada dalam konteks pendidikan secara umum (general education). Tentunya proses tersebut dilakukan dengan sadar dan melibatkan interaksi sistemik antar pelakunya untuk mencapai tujuan yang telah ditetapkan.Pada lingkup sekolah, kepedulian pemerintah terhadap pendidikan jasmani telah diwujudkan melalui penerapan Kurikulum 2013 dengan ditambahnya jam pembelajaran pendidikan jasmani yang awalnya hanya dua jam pembelajaran menjadi tiga jam pembelajaran.

Permasalahan utama yang dihadapi pendidikan jasmani saat ini adalah terjadinya perubahan nilai budaya, dari budaya gerak menjadi budaya diam. Pergeseran budaya tersebut dipicu oleh dampak globalisasi ekonomi, teknologi komunikasi dan transportasi serba otomatis sehingga siswa cenderung menghilangkan aktivitas fisik dalam berbagai kegiatannya.

Sehubungan dengan pernyataan di atas, pembinaan olahraga di sekolah dasar melalui program pendidikan jasmani mustahil dapat berhasil dengan baik, apabila siswa tidak menyenangi salah satu olahraga yang masuk ke dalam kelompok mata pelajaran intra kurikuler yaitu senam, atletik, dan permainan. Berdasarkan observasi ke beberapa sekolah dasar yang ada di Kota Bandung dan hasil wawancara dengan guru pendidikan jasmani, olahraga atletik merupakan mata pelajaran yang kurang disenangi oleh para siswa.

Massin (2000) mengemukakan bahwa salah satu penyebab kurang disenanginya mata pelajaran atletik di sekolah-sekolah adalah atletik tidak dijadikan suatu aktivitas yang menarik bagi siswa. Dengan demikian peran guru haruslah merencanakan program-program pembelajaran yang dapat memberikan kegembiraan dan motivasi kepada siswa dalam proses belajar mengajar atletikPara guru seharusnya menyadari bahwa kegembiraan memegang peranan penting dalam proses belajar, termasuk dalam proses belajar mengajar atletik. Kegembiraan merupakan unsur penting untuk membangkitkan motivasi. Motivasi menjadi amat tinggi ketika tantangan atau kesulitan tugas yang dihadapi seimbang dengan keterampilan yang dimiliki oleh siswa. Keseimbangan antara kedua hal ini akan menimbulkan kegairahan dalam belajar.

Hal tersebut sejalan dengan yang dikemukakan Ibrahim (2001:29-31),yaitu kegairahan dalam belajar ditandai dengan munculnya kegembiraan dan pemakaian waktu yang optimal dalam proses belajar gerak. Sebaliknya, ketidakseimbangan antara tugas gerak dengan kemampuan atau keterampilan siswa akan menyebabkan dua kemungkinan yaitu kebosanan (apabila tantangan rendah, sementara keterampilan tinggi) dan kecemasan (apabila tugas gerak tinggi, sementara keterampilan rendah).

Kegembiraan lazimnya akan muncul dalam suasana bermain. IAAF (Suyono, 2002) mengemukakan bahwa bermain dalam atletik (Kid's Athletics) merupakan model pembelajaran yang dapat digunakan untuk membangkitkan kegembiraan siswa dalam belajar atletik di sekolah. Sehingga atletik tidak lagi menjadi mata pelajaran yang membosankan dan monoton tetapi menjadi mata pelajaran yang menarik bagi siswa.

Model pembelajaran bermain dalam atletik (Kid's Athletics) sebetulnya bukan hal yang baru, banyak literatur yang membahas dengan gamblang disertai gambar bermain dalam atletik. Tetapi berdasarkan observasi di beberapa sekolah di Kota Bandung, model pembelajaran bermain dalam atletik (Kid's Athletics) jarang dilaksanakan dalam proses belajar mengajar atletik. Sehingga image atletik yang tidak menarik dan membosankan terus terjadi dalam diri siswa.

IAAF, (Suyono, 2002) mengemukakan bahwa dewasa ini sering kita lihat bahwa pengajaran pendidikan jasmani di sekolah dasar dilaksanakan secara tradisional di mana kegiatan yang dilakukan siswa sama dengan apa yang dilakukan oleh guru tanpa modifikasi. Seharusnya ada modifikasi, baik dalam aturan, ukuran alat, lapangan, dan jumlah pemain. Hal ini perlu dilakukan agar sesuai dengan kemampuan siswa, sehingga siswa dapat ikut berpartisipasi aktif, senang, dan ber- 
gairah dalam mengikuti pelajaran. Andaikan tidak dilakukan modifikasi dikhawatirkan akan terjadi sebaliknya, anak akan sering mengalami kegagalan dan kekecewaan sehingga akhirnya dapat menumbuhkan rasa tidak senang dan frustasi.

Konsep Kid's Athletics dan konsep bermain dalam atletik adalah sama yaitu aktivitas bermain yang menyenangkan dalam atletik. Kedua konsep ini bukan untuk menggantikan konsep atletik Konvensional (tradisional), tetapi sebagai alternatif untuk mempelajari teknik-teknik dasar atletik yang penuh dengan kegembiraan, sehingga relatif terbebas dari sifat-sifat kaku dari model Konvensional (tradisional). Hal ini sejalan dengan yang dikemukakan Rini, Tasmin, yaitu bahwa aktivitas yang menyenangkan dalam atletik, siswa akan menangkap keadaan pribadinya yang asli pada saat melakukan permainan, baik watak asli maupun kebiasaan yang telah membentuk kepribadiannya. Dengan demikian dapat dikatakan bahwa dengan bermain siswa dapat mengaktualisasikan potensi aktivitas manusia dalam bentuk gerak, sikap, dan perilaku

Selanjutnya, Massin (2000) mengemukakan bahwa Kid's Athletics memberikan kesempatan kepada siswa untuk mendemontrasikan dan mengilhami daya tarik atau pesona tentang atletik di tempat umum, misalnya di pusat-pusat rekreasi, pusat-pusat belanja, dan gedung olahraga. Jadi Kid's Athletics dapat diperkenalkan dengan caracara yang tidak dapat dibayangkan sebelumnya. Kid's Athletics telah menunjukan kesan yang baru, lengkap, dan luas kepada siswa tentang atletik yang menyenangkan atau menggembirakan.
Berdasarkan uraian yang telah dikemukakan tersebut, model pembelajaran Kid's Athletics untuk anak usia dini (usia sekolah) belum teruji keefektifannya terhadap penguasaan teknikdasar atletik. Oleh sebab itu tujuan penelitian secara umum adalah untuk mengkaji dan mencari informasi mengenai pengaruh model pembelajaran dan koordinasi mata tangan kaki terhadap hasil belajar keterampilan lari cepat.

Secara khusus tujuan penelitian ini adalah: (1) mengetahui perbedaan antara model pembelajaran Kid's Athleticsdan model pembelajaran Konvensional terhadap hasil belajar keterampilan lari cepat secara keseluruhan; (2) mengetahui Interaksi antara model pembelajaran dan koordinasi mata tangan kaki terhadap hasil belajar keterampilan lari cepat; (3) mengetahui perbedaan antara model pembelajaran Kid's Athleticsdan model pembelajaran Konvensional terhadap hasil belajar keterampilan lari cepat pada siswa yang memiliki koordinasi mata tangan kaki tinggi; dan (4) mengetahui perbedaan antara model pembelajaran Kid's Athleticsdan model pembelajaran Konvensional terhadap hasil belajar keterampilan lari cepat pada siswa yang memiliki koordinasi mata tangan kaki rendah.

\section{METODE}

Penelitian dilaksanakan di Sarana Olahraga Ganesa (SARAGA) UPT Olahraga ITB Kota Bandung Jawa Barat. Penelitian dilakukan sembilan minggu, dengan frekuensi latihan dua kali dalam satu minggu (menyesuaikan dengan jadwal pelajaran olahraga sekolah) dengan adanya selang waktu latihan atau perlakuan. Dengan demikian

Tabel 1. Disain Treatment by Level2 $x 2$

\begin{tabular}{|c|c|c|c|}
\hline \multirow{2}{*}{\multicolumn{2}{|c|}{$\begin{array}{c}\text { Koordinasi Mata } \\
\text { Tangan Kaki } \\
(B)\end{array}$}} & \multicolumn{2}{|c|}{$\begin{array}{l}\text { Model Pembelajaran } \\
(A)\end{array}$} \\
\hline & & Model Kid's Athletics $\left(A_{l}\right)$ & Model Konvensional $\left(\mathrm{A}_{2}\right)$ \\
\hline & Tinggi $\left(B_{l}\right)$ & $A_{1} B_{1}$ & $A_{2} B_{1}$ \\
\hline & Rendah $\left(B_{2}\right)$ & $A_{1} B_{2}$ & $A_{2} B_{2}$ \\
\hline \multicolumn{4}{|c|}{ Keterangan: } \\
\hline$A_{1}$ & \multicolumn{3}{|c|}{$=$ Kelompok model pembelajaran Kid's Athletics } \\
\hline & \multirow{2}{*}{\multicolumn{3}{|c|}{$=$ Kelompok model pembelajaran Konvensional }} \\
\hline & \multicolumn{2}{|c|}{$=$ Kelompok koordinasi mata tangan tinggi } & \\
\hline & \multicolumn{3}{|c|}{$=$ Kelompok koordinasi mata tangan rendah } \\
\hline$A_{1} B_{1}$ & \multicolumn{3}{|c|}{$\begin{aligned}= & \text { Hasil belajar keterampilan lari cepat meng } \\
& \text { mata tangan tinggi }\end{aligned}$} \\
\hline$A_{1} B_{2}$ & \multicolumn{3}{|l|}{$\begin{aligned}= & \text { Hasil belajar keteram } \\
& \text { mata tangan rendah }\end{aligned}$} \\
\hline$A_{2} B_{1}$ & \multicolumn{3}{|c|}{$\begin{aligned}= & \text { Hasil belajar keterampilan lari cepat menggunakan model pembelajaran Konvensionalpada siswa dengan koordinasi } \\
& \text { mata tangan tinggi }\end{aligned}$} \\
\hline$A_{2} B_{2}$ & \multicolumn{3}{|c|}{$\begin{aligned}= & \text { Hasil belajar keterampilan lari cepat menggunakan model pembelajaran Konvensionalpada siswa dengan koordinasi } \\
& \text { mata tangan rendah }\end{aligned}$} \\
\hline
\end{tabular}


jumlah latihan atau perlakuan sebanyak 18 kali pertemuan.

Metode penelitian yang digunakan adalah eksperimen. Fraenkel, Wallen, (2006) mengemukakan metode eksperimen sering digunakan karena dianggap sebagai metode yang paling kuat yang ada untuk mempelajari hubungan sebab akibat. Adapun rancangan penelitiannya adalah dengan disain Treatment by Level 2 x 2. Bentuk dari rancangan penelitian seperti yang terlihat dalam Tabel 1.

Populasi terjangkau adalah siswa Sekolah Dasar Prof. Dr. Moestopo kelas 4, kelas 5, dan kelas 6 Kota Bandung Jawa Barat tahun.Data hasil tes keterampilan lari cepat, sedang analisis data dilakukan dengan menggunakan teknik analisis varians (Gall dkk, 2003:405). Berdasarkan hasil analisis varians menunjukkan adanya pengaruh utama antara variabel bebas terhadap variabel terikat, dan terdapat interaksi antara variabel bebas hubungannya dengan variabel terikat, maka analisis dilanjutkan dengan uji Tukey atau Tukkey's HSD (honestly significant difference) test(Kirk, 1982). Sebagai syarat pengujian terlebih dahulu melakukan uji normalitas dengan Liliefors dan uji homogenitas dengan Barlett.

\section{HASIL DAN PEMBAHASAN \\ Hasil}

Berdasarkan hasil penelitian diperoleh data pada setiap kelompok belajar keterampilan lari cepat dapat dilihat pada Tabel 2 dan Tabel 3.

\section{Perbedaan Keterampilan Lari Cepat Dua Model Pembelajaran}

Berdasarkan hasil pengolahan dan analisis varians mengenai pengaruh model pembelajaran Kid's Athletics dibandingkan dengan model

Tabel 2. Rangkuman Deskripsi Data Keterampilan Lari Cepat Secara Umum

\begin{tabular}{|c|c|c|c|c|}
\hline \multirow[b]{2}{*}{$\begin{array}{l}\text { Koordinasi Mata } \\
\text { Tangan Kaki }\end{array}$} & \multirow[b]{2}{*}{$\begin{array}{l}\text { Sumber } \\
\text { Statistik }\end{array}$} & \multicolumn{3}{|c|}{ Model Pembelajaran } \\
\hline & & $\begin{array}{l}\text { Pendekatan } \\
\text { Kid's Athletics }\end{array}$ & $\begin{array}{l}\text { Pendekatan } \\
\text { Konvensional }\end{array}$ & TOTAL \\
\hline \multirow{5}{*}{ Tinggi $\left(B_{l}\right)$} & $\mathrm{N}$ & 10 & 10 & 20 \\
\hline & $\overline{\mathrm{X}}$ & 663.5 & 583 & 623.25 \\
\hline & $\mathrm{S}$ & 19,3 & 31,9 & \\
\hline & $\Sigma X$ & 6635 & 5830 & 12465 \\
\hline & $\Sigma X^{2}$ & 4405675 & 3408050 & 7813725 \\
\hline \multirow{5}{*}{ Rendah $\left(B_{2}\right)$} & $\mathrm{N}$ & 10 & 10 & 20 \\
\hline & $\overline{\mathrm{X}}$ & 537.5 & 572 & 554.75 \\
\hline & $\mathrm{S}$ & 18,44 & 26,79 & \\
\hline & $\Sigma \mathrm{X}$ & 5330 & 5720 & 11050 \\
\hline & $\Sigma X^{2}$ & 2843950 & 3278300 & 6122250 \\
\hline \multirow{5}{*}{ TOTAL } & $\mathrm{N}$ & 20 & 20 & 40 \\
\hline & $\overline{\mathrm{X}}$ & 600.5 & 577.5 & 589 \\
\hline & S & 68,8 & 29,2 & \\
\hline & $\Sigma X$ & 11965 & 11550 & 23515 \\
\hline & $\Sigma X^{2}$ & 7249625 & 6686350 & 13935975 \\
\hline
\end{tabular}

Tabel 3. Rangkuman Hasil ANAVA Dua Jalan

\begin{tabular}{lcccccc}
\hline $\begin{array}{c}\text { Sumber } \\
\text { Variasi } \\
\text { (Antar) }\end{array}$ & JK & $\mathbf{d k}$ & RJK & $F h=\frac{R K}{R K D}$ & $\begin{array}{c}\mathbf{F t} \\
\boldsymbol{\alpha}=\mathbf{0 , 0 5} \\
(\mathbf{1 : 3 6})\end{array}$ & Keterangan \\
\hline JKA(b) & 50055.625 & 1 & 50055.63 & 81.79 & 4,11 & Signifikan \\
JKA(k) & 4305.625 & 1 & 4305.625 & 7.04 & 4,11 & Signifikan \\
JKA(bk) & 35700.625 & 1 & 35700.63 & 58.3 & 4,11 & Signifikan \\
JKD & 22032.5 & 36 & 612.0139 & & & \\
$\quad$ Total & 112094.375 & 39 & - & & & \\
\hline
\end{tabular}


pembelajaran Konvensional terhadap hasil belajar keterampilan lari cepat secara keseluruhan dapat dilihat pada Tabel 3. Hasil dari pengolahan dan analisis diketahui bahwa terdapat perbedaan antara model pembelajaran Kid's Athletics dibandingkan dengan model pembelajaran Konvensional. Hipotesis nol yang menyatakan tidak ada perbedaan keterampilan lari cepat antara siswa yang menggunakan model pembelajaran Kid's Athletics dan model pembelajaran Konvensional ditolak. Artinya, bahwa ada perbedaan yang signifikan Antara keterampilan lari cepat siswa yang menggunakan model pembelajaran Kid's Athletics dengan siswa yang menggunakan model pembelajaran Konvensional. Keterampilan lari cepat siswa yang menggunakan model pembelajaran Kid's Athletics lebih tinggi atau lebih baik dibandingkan dengan yang menggunakan model pembelajaran Konvensional Hipotesis penelitian yang menyatakan bahwa secara keseluruhan, model pembelajaran Kid's Athletics diduga lebih tinggi pengaruhnya dari model pembelajaran Konvensional terhadap hasil belajar keterampilan lari cepat telah teruji.

Selanjutnya untuk dapat mengetahui tingkat perbedaan antar kelompok dilakukan dengan uji lanjut, yaitu Tukey. Hasil uji Tukey diperoleh nilai harga $\mathrm{q}=3,75$ lebih besar dari $\mathrm{q}_{\text {tabel }}\left(\mathrm{q}_{\mathrm{t}}\right)=$ 2,88 pada taraf signifikansi $\alpha=0,05$, dengan $\mathrm{dk}$ 2,36 sehingga $\mathrm{H}_{0}$ ditolak. Dengan demikian, dapat disimpulkan bahwa terdapat perbedaan yang signifikan hasil belajar keterampilan lari cepat antara model pembelajaran Kid's Athletics dengan model pembelajaran Konvensional. Model pembelajaran Kid's Athletics memiliki pengaruh lebih baik terhadap hasil belajar keterampilan lari cepat dibandingkan dengan model pembelajaran Konvensional.

\section{Interaksi antara Model Pembelajaran}

Hipotesis nol yang menyatakan tidak terdapat interaksi antara model pembelajaran dan koordinasi mata tangan kaki terhadap hasil belajar keterampilan lari cepat ditolak. Artinya, bahwa terdapat interaksi antara model pembelajaran dan koordinasi mata tangan kaki terhadap hasil belajar keterampilan lari cepat 60 meter. Gambar 1 menunjukkan interaksi untuk lebih memperjelas hasil analisis.

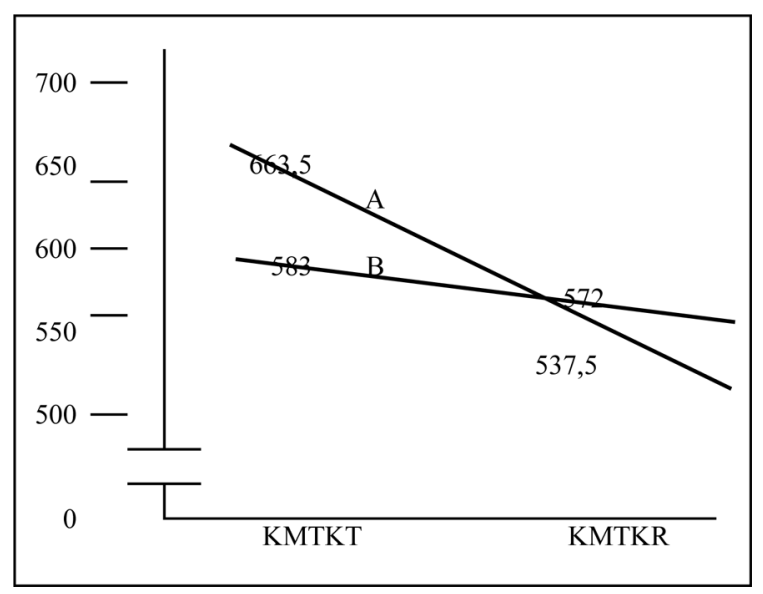

Gambar 1. Garis Interaksi antara Model Pembelajaran dengan Koordinasi Mata Tangan Kaki terhadap Hasil Belajar Keterampilan Lari Cepat

Keterangan:

$\begin{array}{ll}\text { A } & =\text { Model pembelajaran Kid's Athletics } \\ \mathrm{B} & =\text { Model pembelajaran Konvensional } \\ \text { KMTKT } & =\text { Koordinasi mata tangan kaki tinggi } \\ \text { KMTKR } & =\text { Koordinasi mata tangan kaki rendah }\end{array}$

\section{Perbedaan Keterampilan Lari Cepat}

Hasil pengolahan dan analisis varians dengan ANAVA dan uji lanjut dengan Tukey diketahui bahwa keterampilan lari cepat meter antara siswa yang menggunakan model pembelajaran Kid's Athletics kemampuan koordinasi mata tangan kaki tinggi $\left(A_{l} B_{l}\right)$ dengan yang menggunakan model pembelajaran Konvensional pada siswa kemampuan koordinasi mata tangan kaki tinggi terdapat $\left(A_{2} B_{l}\right)$ terdapat perbedaan yang signifikan. Artinya, hasil pembelajaran keterampilan lari cepat pada siswa yang menggunakan model pembelajaran Kid's Athletics dengan koordinasi mata tangan kaki tinggi, lebih baik dibandingkan dengan yang menggunakan model pembelajaran Konvensional $\left(\overline{\mathrm{X}}_{\mathrm{A} 1 \mathrm{~B} 1}=663,5>\overline{\mathrm{X}}_{\mathrm{A} 2 \mathrm{~B} 1}=583\right)$. Hal ini berarti bahwa hipotesis kerja diterima.

Hasil pengolahan dan analisis varians dengan ANAVA dan uji lanjut dengan Tukey diketahui bahwa keterampilan lari cepat antara siswa yang menggunakan model pembelajaran Kid's Athletics kemampuan koordinasi mata tangan kaki $\left(A_{1} B_{2}\right)$ dengan yang menggunakan model pembelajaran Konvensional pada siswa kemampuan koordinasi mata tangan kaki tinggi terdapat $\left(A_{2} B_{2}\right)$ perbedaan yang signifikan. Pada kelompok $A_{1} B_{l}$ dan $A_{2} B_{1}$ diketahui harga $\mathrm{q}=11,696$ lebih besar dari $\mathrm{q}_{\mathrm{t}}=3,79$. Dengan demikian, hipotesis nol ditolak. Artinya, hasil pembelajaran keterampilan 
lari cepat pada siswa yang menggunakan model pembelajaran Kid's Athletics dengan koordinasi mata tangan kaki rendah, memiliki pengaruh lebih rendah dibandingkan dengan yang menggunakan model pembelajaran Konvensional $\left(\overline{\mathrm{X}}_{\mathrm{A} 1 \mathrm{~B} 2}=533\right.$ $\left.>\bar{X}_{\mathrm{A} 2 \mathrm{~B} 2}=572\right)$. Hal ini berarti bahwa hipotesis kerja diterima.

\section{Pembahasan}

Berdasarkan hasil analisis data, penulis paparkan pembahasan hasil analisis data sebagai berikut:

\section{Perbedaan Keterampilan Lari Cepat Model Pembelajaran Kid's Athletics Model Konven- sional}

Berdasarkanhasil pengolahan dan analisis data penelitian, diperoleh hasil bahwa hipotesis yang menyatakan bahwa model pembelajaran Kid's Athletics lebih tinggi pengaruhnya dari model pembelajaran Konvensional terhadap hasil belajar keterampilan lari cepat diterima. Artinya bahwa model pembelajaran Kid's Athletics memberikan pengaruh lebih baik dibandingkan dengan model pembelajaran Konvensional dalam mempelajari keterampilan lari cepat.

Model pembelajaran Kid's Athletics merupakan konsepsi baru tentang atletik untuk usia dini yang memformulasikan gerakan-gerakan dasar atletik (lari, lompat, dan lempar) ke dalam suatu suasana bermain yang menyenangkan, menarik, dan tidak membosankan (IAAF, 2002). Tujuan dari model pembelajaran Kid's Athletics adalah memberikan motivasi dan kegembiraan kepada para siswa dengan latihan-latihan gerak yang beragam dalam lingkup individu atau suatu tim, dengan lokasi latihan yang berbeda-beda, alat bantu latihan hasil modifikasi yang menarik, dan relatif tidak membutuhkan tempat latihan atau bermain yang luas.

Keunggulan dari model pembelajaran Kid's Athletics dibandingkan dengan model pembelajaran Konvensional adalah siswa dapat mempelajari gerak dalam atletik secara keseluruhan tetapi dalam suasana yang menyenangkan, karena aktivitas dikemas dalam bentuk modifikasi bermain yang sesuai dengan usia anak.

Bemain merupakan sebuah kegiatan yang berkaitan dengan manusia, sehingga manusia disebut juga makhluk bermain (Homo Ludens). Bermain merupakan kegiatan rekreasi yang banyak dilakukan orang, karena bermain akan mem- berikan perasaan senang dan gembira. Tjandrasa (1980) mengemukakan bahwa bermain adalah setiap kegiatan yang dilakukan karena kesenangan yang ditimbulkannya, tanpa mempertimbangkan hasil akhir, bermain dilakukan secara sukarela dan tanpa paksaan atau tekanan dari luar kewajiban. Dengan aktivitas bermain proses pembelajaran dapat terasa menyenangkan karena tidak terbebani agar harus menang, menjadi nomor satu dan lain sebagainya.

Bermain menunjukkan realitas anak, yaitu adaptasi terhadap apa yang sudah mereka ketahui dan respon mereka terhadap hal-hal baru. Kegiatan bermain dapat dilakukan anak dengan sungguh-sungguh, mereka melakukannya dengan sepenuh hati demi tercapainya tujuan yang mereka inginkan. Bermain dapat menjadi sesuatu yang serius bagi anak-anak, di dalam bermain anak menumpahkan seluruh perasaannya. Keinginan bermain timbul karena minat pada diri seseorang untuk bergerak sesuai kebutuhan, memelihara kondisi tubuh, mengasah keterampilan serta menghilangkan kejenuhan (Fajar, 1996).

Bentuk-bentuk perlakuan Kid's Athletics untuk nomor sprint yaitu Sprint Hurdles, Sprint Slalom, dan Formula-1 yang dihubungkan ke dalam konteks atletiknomor sprint adalah merupakanragam aktivitas yang akan memberikan dampak yang lebih baik dibandingkan dengan hanya satu ragam saja (IAAF, (2002).

Keunggulan model pembelajaran Kid's Athletics dengan Konvensionalsecara keseluruhan disajikan dalam Tabel 4.

\section{Interaksi Model Pembelajaran dan Kemam- puan Koordinasi Mata Tangan terhadap Hasil Belajar Keterampilan Lari Cepat}

Hasil dari pengujian hipotesis diketahui bahwa terdapat interaksi antara model pembelajaran dan kemampuan koordinasi mata tangan kaki terhadap hasil belajar keterampilan lari cepat. Interaksi keduanya terlihat pada adanya perbedaan pengaruh perlakuan terhadap keterampilan lari cepat pada kedua tingkat kemampuan koordinasi mata tangan siswa.

Permasalahan ini menunjukkan bahwa dalam menentukan penggunaan model pembelajaran Kid's Athletics hendaknya terlebih dahulu dapat memperhatikan kemampuan koordinasi mata tangan kaki siswa. Pada siswa yang memiliki koordinasi mata tangan kaki tinggi, model pembelajaran Kid's Athletics akan lebih efektif 
Tabel 4. Perbandingan Model Pembelajaran Kid's Athletics dengan Model Pembelajaran Konvensional

\section{MODEL PEMBELAJARAN}

\begin{tabular}{ll}
\hline \multicolumn{1}{c}{ Kid's Athletics } & \multicolumn{1}{c}{ Konvensional } \\
\hline $\begin{array}{l}\text { Pembelajaran dalam suasana bermain, menyenangkan, } \\
\text { menarik, dan tidak membosankan. (IAAF, 2002). }\end{array}$ & $\begin{array}{l}\text { Guru sebagai subjek yang aktif dan siswa } \\
\text { sebagai objek yang pasif. (Freire, 1999). }\end{array}$ \\
\hline $\begin{array}{l}\text { Siswa usia 7-13 tahun menekankan pada latihan dasar } \\
\text { gerak atletik umum terutama pada keterampilan }(s k i l l)\end{array}$ & $\begin{array}{l}\text { Terjadi passive learning, interaksi di antara } \\
\text { siswa kurang, tidak ada kelompok-kelompok } \\
\text { dan kecepatan (Lumintuarso, 2011). }\end{array}$ \\
$\begin{array}{ll}\text { kooperatif, dan penilaian bersifat sporadik. } \\
\text { (Burrowes, 2003). }\end{array}$ \\
$\begin{array}{l}\text { Menekankan latihan untuk cabang olahraga atletik } \\
\text { berdasarkan usia anak (Lumintuarso, 2011). }\end{array}$ & $\begin{array}{l}\text { Belajar dilihat sebagai proses"meniru”. } \\
\text { (Brooks \& Brooks, 1993). }\end{array}$ \\
$\begin{array}{l}\text { Memberikan motivasi dan kegembiraan kepada para } \\
\text { siswa dengan latihan-latihan gerak yang beragam, } \\
\text { lokasi latihan yang berbeda-beda, alat bantu latihan } \\
\text { dimodifikasi, dan relatif tidak membutuhkan tempat } \\
\text { latihan atau bermain yang luas. (Suyono, 2002). }\end{array}$ & $\begin{array}{l}\text { Sering memberikan konsep-konsep gerak } \\
\text { yang sulit cenderung akan menurunkan. } \\
\text { akan menyebabkan para siswa kurang tertarik } \\
\text { bahkan menjadi bosan (Kesimpulan penulis, } \\
\text { 2013). }\end{array}$ \\
\hline
\end{tabular}

apabila digunakan. Sedangkan untuk siswa dengan kemampuan koordinasi mata tangan kaki rendah akan lebih efektif apabila digunakan model pembelajaran Konvensional.

Adams (1988) menyampaikan bahwa gerak bagi anak memiliki arti sebagai berikut. (1) Hidup, gerakan siswa bukan hanya kepentingan hidupnya sendiri, tetapi juga kelengkapan hidupnya. (2) Penemuan diri, gerak yang dilakukan anak dalam bentuk kegiatan permainan, mulai dari awal kekagumannya terhadap fungsi gerak yang instingtif sampai keterbatasannya pada keterampilan olahraga. (3) Penemuan lingkungan, melalui kegiatan permainan yang dilakukan, siswa dapat menemukan dan melewati batas hak dan milik orang lain. (4) Kebebasan, kebebasan dimaksud adalah kebebasan yang berorientasi pada pemberian gerak dan aktivitas yang bebas dari hambatan dan keterbatasan jasmani. (5) Keamanan, dalam melakukan permainan ada beberapa hal mendasar pada gerakan untuk mempunyai nilai mempertahankan hidup. (6) Hubungan, gerak yang dilakukan oleh tubuh merupakan gerakan yang memiliki arti sebagai bahasa tubuh. (7) Kegembiraan, dengan gerakan yang berhasil, anak akan menikmati rasa gembira dan dinyatakan dalam ungkapan perilaku. (8) Unggul, ritmik, dan anggun.

Pada pembelajaran penjas dan olahraga, gerak merupakan unsur utama yang digunakan dalam upaya mendidik manusia baik secara kognitif, afektif maupun psikomotorik. Gerak merupakan kunci dari pendidikan jasmani dan
olahraga.Istilah belajar keterampilan gerak banyak dikemukakan oleh para ahli diantaranya adalah Schmidt. Schmidt (1991) mengemukakan bahwa belajar keterampilan gerak adalah serangkaian proses yang berhubungan dengan latihan atau pengalaman yang mengarah pada terjadinya perubahan-perubahan yang relatif permanen dalam kemampuan seseorang untuk menampilkan gerakan-gerakan terampil.

Belajar keterampilan gerak dalam bidang olahraga tidak terlepas dari pembelajaran gerak atau pelatihan gerak manusia, yang lebih popular dengan istilah keterampilan gerak. Apabila siswa sejak usia dini kurang memperoleh kesempatan untuk belajar keterampilan gerak, maka pada tahap usia selanjutnya akan lebih banyak gagal dalam melaksanakan tugas geraknya (cacat gerak) (Lutan, 2001).

Untuk mempercepat proses pembentukan gerak yang baru pada siswa, sebaiknya dikembangkan berdasarkan pengalaman-pengalaman yang pernah dialami siswa tersebut. Semakin banyak pengalaman anak tentang gerak, maka semakin cepat dan mudah anak menguasai gerak yang baru dikuasai. Oleh karenanya apabila anak ingin menguasai suatu keterampilan gerak, maka yang harus dilakukan oleh guru atau pelatih adalah memberikan kesempatan terhadap anak untuk dapat melakukan gerakan tersebut secara terus menerus dan sistematis. Pengalaman gerak yang banyak akan membantu membelajarkan anak dalam upaya meningkatkan kemampuan motorik 
yang ingin dikuasai, sebab tanpa pengalaman secara langsung maka suatu keterampilan motorik niscaya dapat terjadi.

Ada dua variable pokok yang mempengaruhi belajar keterampilan gerak, yaitu variabel lingkungan yang terdiri atas sub variabel umpan balik, kondisi latihan, dan variabel individual yang merangkum sub variabel kemampuan perseptual dan kemampuan motorik. Variabel lain yang dapat mempengaruhi keterampilan motorik adalah motivasi, kombinasi metode belajar holistic dengan parsial, transfer keterampilan, kondisi latihan, umpan balik, penguatan, dan perbedaan individual seperti latar belakang sosial ekonomi, pengalaman masa lalu, kemampuan motorik, kecerdasan, dan kepribadian.

Proses penguasaan keterampilan gerak berlangsung melalui tahap-tahap waktu. Tahap kritis adalah suatu tahap dimana pembinaan gerak harus dilakukan, jika tidak, maka keterampilan gerak siswa akan terhambat atau kurang berkembang. Prustasi akibat kegagalan melaksanakan suatu tugas gerak akan terjadi dan berlanjut sampai dewasa. Pembinaan keterampilan dasar penting dilakukan di usia sekolah dasar. Pada masa ini seyogyanya ditekankan kepada pengayaan dan pengembangan keterampilan geraknya. Semakin banyak perbendaharaan gerak dasarnya, semakin terampil siswa melaksanakan keterampilan lainnya. Dengan demikian, akan ada keterampilan yang selamanya tidak sempat untuk dipelajari (Lutan, 2001).

Magill (1980) menyampaikan bahwa dalam proses belajar berlatih faktor kemampuan gerak yang mendukung kemampuan keterampilan dalam suatu cabang olahraga harus mendapat perhatian dari guru dan pelatih olahraga. Terdapat dua aspek pokok kemampuan gerak yaitu kemampuan gerak perseptual dan kemampuan ketangkasan fisik. Kemampuan perseptual berkaitan dengan waktu reaksi, kecepatan, kecepatan gerak lengan, pengontrolan kecepatan, dan kemampuan membidik. Sedangkan kemampuan ketangkasan fisik berkaitan dengan motor ability seperti kekuatan, statis/dinamis, power, koordinasi secara menyeluruh, dan daya tahan jantung dan paru-paru. Pada cabang olahraga atletik beberapa aspek perseptual dan kemampuan fisik sangat menentukan dalam pencapaian prestasi yang optimal.
Perbedaan Keterampilan Lari Cepat Model Pembelajaran Kid's Athletics dan Konvensional Siswa yang Memiliki Koordinasi Mata Tangan Kaki Tinggi

Hasil penelitian menunjukkan adanya perbedaan yang signifikan hasil keterampilan lari cepat antara model pembelajaran Kid's Athletics dengan model pembelajaran Konvensional pada siswa yang memiliki koordinasi mata tangan kaki tinggi. Pada siswa yang memiliki kemampuan koordinasi mata tangan kaki tinggi menggunakan model pembelajaran Kid's Athletics memperoleh hasil keterampilan lari cepat lebih tinggi dibandingkan dengan yang menggunakan model pembelajaran Konvensional.

Pendekatan pembelajaran Kid's Athletics dengan pendekatan multilateral yang bersifat menyenangkan. Kid's Athletics ditujukan pada aspek aktivitas bermain tetapi fokusnya adalah pada proses belajar, berlatih, dan praktek yang tidak boleh lepas dari pengawasan seorang guru. Setiap tahap latihan, daya fantasi guru atau pelatih sangat dituntut agar tercipta suasana bermain yang menggembirakan, menarik tetapi menuntut kedisiplinan dari para siswa. Kondiri tersebut memungkinkan model pembelajaran Kid's Athletic memberikan pengaruh lebih besar terhadap hasil pembelajaran lari cepat pada siswa dibandingkan dengan model pembelajaran Konvensional.

Pembinaan multilateral yang juga disebut multi skill adalah pengembangan berbagai keterampilan dan kemampuan motorik (motor ability) dengan adaptasi berbagai kebutuhan beban latihan untuk mengembangkan adaptasi menyeluruh. Dengan dikembangkannya aspek tersebut secara integral akan tercapai porsi tubuh yang harmonis. Anak yang memiliki landasan multilateral yang kuat akan dapat mencapai kinerja olahraganya dengan lebih baikdibandingkan dengan anak yang tidak memiliki fondasi multilateral (Bompa, 1999).

Hal tersebut diperkuat dengan pendapat Gabbard (Lumintuarso, 2010) yang menyampaikan bahwa, pengembangan multilateral dalam fase pengembangan skill sebagai movement variability (keberagaman gerak), dimana keberagaman gerakan inimerupakan penyediaan variasi pengalaman gerak dengan tema tertentu. Dengan penyediaan pengalaman gerak yang beragam ini anak akan memiliki pola dan kesadaran gerak yang lebih kuat untuk mampu berkinerja dengan lebih efisien dalam berbagai situasi yang bervariasi. 
Pendapat tersebut didukung oleh bentukbentuk perlakuan Kid's Athletics untuk nomor lari cepat (sprint) yaitu Sprint Hurdles, Sprint Slalom, dan Formula-1 yang dihubungkan ke suatu konteks atletiknomor sprint. Bentuk-bentuk perlakuan ini dapat memotivasi para siswa untuk menampilkan keterampilan berlari yang telah dikuasainya tanpa merasa bosan meskipun menyita waktu yang relatif lama (IAAF, 2002).

Ditinjau dari sisi unit latihannya menyajikan sebuah tuntunan penekanan latihan untuk cabang olahraga atletik berdasarkan usia anak. anak pada usia 7-13 tahun masih menekankan diri pada latihan dasar gerak atletik umum terutama pada keterampilan (skill) dan pada kecepatan. Sedangkanlatihan keterampilankhusus dimulai setelah 14 tahun dengan diikuti latihan kecepatan, kekuatan dan daya tahan (Lumintuarso, 2011).

\section{Perbedaan Keterampilan Lari Cepat Model Pembelajaran Kid's Athletics dan Konvensional pada Siswa yang Memiliki Koordinasi Mata Tangan Kaki Rendah}

Pada siswa yang memiliki kemampuan koordinasi mata tangan kaki rendah menggunakan model pembelajaran Kid's Athletics memperoleh hasil keterampilan lari cepat lebih rendah dibandingkan dengan yang menggunakan model pembelajaran Konvensional. Ini menunjukkan bahwa kemampuan koordinasi mata tangan kaki juga memberikan pengaruh terhadap hasil belajar keterampilan lari cepat. Siswa dengan kemampuan koordinasi mata tangan kaki rendah cenderung kurang memberikan dampak secara signifikan apabila diberikan model pendekatan Kid's Athletics.

Untuk siswa yang memiliki koordinasi mata tangan kaki rendah, model pembelajaran Konvensional lebih cocok diberikan kepada siswa. Hal ini karena dalam pembelajaran Konvensional, siswa yang memiliki koordinasi mata tangan kaki rendah akan diberikan dril-dril latihan yang lebih intensif. Siswa dipaksa oleh guru untuk selalu melakukan apa yang diperintahkan oleh guru tanpa diberikan kesempatan untuk mengembangkan aktivitas sesuai dengan keinginannya.

Juliantara (2009) menyampaikan bahwa kegiatan mengajar yang dilakukan oleh para guru tersebut merupakan aktivitas menyimpan informasi dalam pikiran siswa yang pasif dan dianggap kosong. Siswa hanya menerima informasi verbal dari buku dan para guru. Penyelenggaraan pen- didikan hanya dipandang sebagai suatu aktivitas pemberian informasi yang harus "ditelan" oleh siswa, yang wajib diingat dan dihafal. Proses ini lebih jauh akan berimplikasi pada terjadinya hubungan yang bersifat antagonism di antara guru dan siswa. Guru sebagai subjek yang aktif dan siswa sebagai objek yang pasif dan diperlakukan tidak menjadi bagian dari realita dunia yang diajarkan kepada mereka.

Jika dilihat dari tiga jalur modus penyampaian pesan pembelajaran, penyelenggaraan pembelajaran Konvensional lebih sering menggunakan modus telling (pemberian informasi), ketimbang modus demonstrating (memperagakan), dan doing direct performance (memberikan kesempatan untuk menampilkan unjuk kerja secara langsung). Guru berasumsi bahwa keberhasilan program pembelajaran dilihat dari ketuntasannya menyampaikan seluruh materi yang ada dalam kurikulum. Penekanan aktivitas belajar lebih banyak pada buku teks dan kemampuan mengungkapkan kembali isi buku teks tersebut. Jadi pembelajaran Konvensional kurang menekankan pada pemberian keterampilan proses.

Terkait dengan temuan ini, Model pembelajaran Konvensional menekankan pada resitasi konten, tanpa memberikan waktu yang cukup kepada siswa untuk merefleksikan materi-materi yang dipresentasikan, menghubungkannya dengan pengetahuan sebelumnya, atau mengaplikasikannya kepada situasi kehidupan nyata. Lebih lanjut dinyatakan bahwa pembelajaran Konvensional memiliki ciri-ciri, yaitu; (1) pembelajaran berpusat pada guru, (2) terjadi passive learning, (3) interaksi di antara siswa kurang, (4) tidak ada kelompok-kelompok kooperatif, dan (5) penilaian bersifat sporadic.

Pendekatan pembelajaran Konvensional memunyai ciri-ciri sebagai berikut: (1) otoritas seorang guru lebih diutamakan dan berperan sebagai contoh bagi para siswanya, (2) perhatian terhadap masing-masing siswa atau minat siswa sangat kecil, (3) pembelajaran di sekolah lebih banyak dilihat sebagai persiapan akan masa depan, bukan sebagai peningkatan kompetensi siswa saat ini, (4) penekanan yang mendasar adalah pada bagaimana pengetahuan dapat diserap oleh siswa dan penguasaan pengetahuan tersebutlah yang menjadi tolok ukur keberhasilan tujuan, sementara pengembangan potensi siswa diabaikan.

Martens (2004) menjelaskan mengenai pendekatan Konvensional sering juga disebut 
pendekatan Tradisional, biasanya guru memberikan latihan dimulai dengan pemanasan, dilanjutkan dengan pembelajaran beberapa keterampilan teknik, dan kemudian melakukan latihan teknik tersebut secara berulang-ulang, dan selanjutnya memberikan instruksi beberapa keterampilan taktik bermain sesuai dengan teknik yang sudah dipelajarinya.

Model pembelajaran Konvensional merupakan model yang cenderung banyak digunakan oleh guru maupun pelatih saat ini di sekolah maupun pada perkumpulan-perkumpulan olahraga. Model ini dianggap cocok karena adanya pandangan bahwa penguasaan teknik dasar lebih utama dalam mendukung penampilan olahraga tanpa memperhatikan dan mempertimbangkan siapa yang menerima pembelajaran. Pandangan tersebut tentu saja keliru terutama dalam dunia pendidikan. Sebuah model pembelajaran belum tentu cocok dan dapat digunakan pada semua level dan jenjang, oleh karenanya setiap aktivitas pembelajaran haruslah memperhatikan siapa subjek yang dibelajarkannya.

\section{PENUTUP}

Berdasarkan hasil penelitian dan pembahasan yang telah dikemukakan di atas, maka dapat ditarik kesimpulan sebagai berikut. (1) Model pembelajaran Kid's Athletics lebih tinggi pengaruhnya dari model pembelajaran Konvensional terhadap hasil belajar keterampilan lari cepat. (2) Terdapat interaksi antara model pembelajaran dan koordinasi mata tangan kaki terhadap hasil belajar keterampilan lari cepat. (3) Siswa yang memiliki koordinasi mata tangan kaki tinggi, model pembelajaran Kid's Athletics lebih tinggi pengaruhnya dari model pembelajaran Konvensional terhadap hasil belajar keterampilan lari cepat. (4) Siswa yang memiliki koordinasi mata tangan kaki rendah, model pembelajaran Kid's Athletics lebih rendah pengaruhnya dari model pembelajaran Konvensional terhadap hasil belajar keterampilan lari cepat.

\section{UCAPAN TERIMA KASIH}

Pada kesempatan ini, penulis mengucapkan terima kasih kepada Dekan Sekolah Farmasi ITB yang telah mendanai penelitian ini. Selanjutnya ucapan terima kasih penulis sampaikan kepada Tim Penyunting yang telah memberi masukan yang berharga sehingga tulisan ini dapat dimuat di Jurnal Cakrawala Pendidikan Universitas Negeri
Yogyakarta. Terima kasih juga penulis ucapkan kepada Redaktur dan segenap pengelola Jurnal Cakrawala Pendidikan yang telah memberikan kesempatan kepada penulis untuk mempublikasikan artikel ini.

\section{DAFTAR PUSTAKA}

Adams. L.R., Pendidikan Jasmani dengan Pendekatan Pemahaman. 1988. dalam Jurnal Abas Sanusi. Jakarta: Ditjen Dikdasmen: 3-4.

Bompa, Tudor O. 1983. Theory and methodology of Training the Key to Athletic Performance.Dubuque: Kendall/Hunt Publishing Company.

Charles A. Bucher dan Wuest, DA. 1995. Foundation of Physical Education and Sport. St. Louis: Mosby: 218-223.

Fajar, Aprilia, et.al. 1996. Ayah Bunda. Dunia Bermain Anak. ayahbunda.com.

Fraenkel, JR., Wallen, NE. 2006. How To Design and Evaluate Research in Education, Sixth Edition. USA: McGraw Hill, Inc: 268.

IAAF, 2002. Atletik untuk Anak-Anak. Terjemahan: H., Suyono, DS. Jakarta: IAAF RDC: 5-7.

IAAF, 2002. Atletik untuk Anak-Anak. Terjemahan: H., Suyono, DS. Jakarta: IAAF RDC: 8.

IAAF, 2002. Atletik untuk Anak-Anak. Terjemahan: H., Suyono, DS. Jakarta: IAAF RDC: 9.

Ibrahim, Rusli. 2001. Landasan Psikologis Pendidikan Jasmani di Sekolah Dasar. Jakarta: Departemen Pendidikan Nasionlal, Direktorat Jenderal Pendidikan Dasar dan Menengah: 29-31.

Kirk, Roger E. 1982. Experimental Design, Procedures for the Behavioral Science. Belmont, California: Wadsworth, Inc: 116.

Lumintuarso, R. 2010. Pembinaan Multilateral dalam Pendidikan Jasmani dan Olahraga Prestasi. Disertasi. UNJ Jakarta: 13-15. 
Lutan, Rusli. 2001. Asas-Asas Pendidikan Jasmani. Pendekatan Pendidikan Gerak di Sekolah Dasar. Jakarta:Departemen Pendidikan Nasional: 39.

Massin, Dieter. 2000. IAAF Kid's Athletics. A Team Event for Children. German: International Association of Athletics Federation: 6 .

Meredith, D.\&Gall. 2003. Educational Research - an Introduction. SeventhEdition. Pearson Educational Inc. USA: 405.

Ma'mun, Amung \& Saputra, Yudha, M. 1999. Perkembangan Gerak dan Belajar Gerak. Bandung: Proyek Penataran Guru SLTP Setara D III: 20.
Martens, Rainer. 2004. Succesful Coaching. Third Edition, American Sport Education Founder. Human Kinetic: Champaign: 84.

Magill, R.A. 1993. Motor Learning, Concept \& Application. Dubuque: WM. C. Brown Publisher: 199.

Rini, Martina, S., Tasmin. "Belajar Lebih Penting Daripada Bermain?," Available Online: http://www.psi.ut.ac.id/data/pend-pra. htm(diakses 16 Oktober 2014).

Schmidth, Richard A. 1991. Motor Learning and Performance. Illionis: Human Kinetics Book: 232.

Suyono, Ds. 2002. Atletik untuk Anak-anak, Suatu Event Beregu/Team Untuk Anak-anak. Jakarta: Staf Set-IAAF RDC. 